\title{
Stable isotope geochemistry of siderite concretions from Jurassic sedimentary rocks on Bornholm (Denmark)
}

\author{
N. B. CHRISTENSEN
}

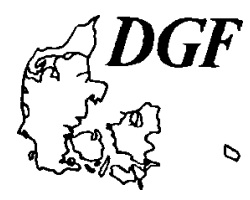

\author{
Christensen, N. B.: Stable isotope geochemistry of siderite concretions from \\ Jurassic sedimentary rocks on Bornholm (Denmark). Bulletin of the Geolological \\ Society of Dep-mark, Vol. 42 , pp. 47-56. Copenhagen, 1995-09-30. \\ https://doi.org/10.37570/bgsd-1995-42-05
}

The diagenetic history of siderite concretions in Mesozoic sedimentary rocks on the island of Bornholm has been investigated using stable isotope-, AAS- and XRD-analysis and determination of carbonate content. Siderite concretions and bands, found in non-marine as well as marine environments, are investigated. The siderite concretions were precipitated from fresh to brackish pore-water prior to compaction.

$\delta^{13} \mathrm{C}_{\mathrm{PDB}}$ values from -14.2 to $+1.4 \mathrm{o} / \mathrm{oo}$ indicate ne ar-surface precipitation affected by bacterial oxidation of organic matter. $\delta^{18} \mathrm{O}$ values between +22.1 and +28.7 o/oo $\delta_{\text {; }}^{18} \mathrm{O}_{\mathrm{w}}$ indicate concretion precipitation in pore-water of fresh to brackish origin. Weathering
effects are seen, but temperature fractionation is not observed.

Nis Brorson Christensen, Nфrregårdsvej 116, 2610 Rфdovre. 17th July 1992.

\section{Introduction}

Concretions form as chemical precipitates in the pore space of sedimentary rocks which act as matrix for the concretionary cement. The stable isotope composition of the concretions reflects pore-water composition and temperature at the time of formation. Their detailed geochemical investigation can provide valuable insight into the diagenetic history of the host rock. Most concretions belong to the calcitic and dolomitic types, and many papers have been published dealing with their geochemistry (e.g. Raiswell 1976, Irwin, Curtis \& Coleman 1977, Coleman \& Raiswell 1981, Buchardt \& Nielsen 1985, Wilkinson 1991, Pirrie \& Marshall 1991). Stable isotope composition of siderite concretions have onlybeen investigated sporadically, partly due to analytical difficulties and partly due to their restricted occurrence (e.g. Curtis, Petrowski \& Oertel 1972, Curtis \& Coleman 1986, Machemer \& Hutcheon 1988, Mozley \& Carothers 1992).

Precipitation of siderite requires high ferrous iron and bicarbonate activity in the pore water. As hydrogen sulphide formed by bacterial reduction of dissolved sulphate is an effective sink for reactive iron, ironpoor carbonates will constitute the majority of the calcareous concretions formed in marine pore water (Gautier 1985). The formation of siderite concretions is generally expected to occur either in pore-water environments dominated by meteoric water (Curtis, Coleman \& Love 1986) or in marine pore water strongly depletedin dissolved sulphate as a result of high sulphate reduction (Irwin 1980, Gautier 1982).
The Jurassic and Lower Cretaceous deposits on the island of Bornholm include several beds rich in early diagenetic siderite developed as concretionary bodies or continuous concretionary horizons. During the Jurassic and Early Cretaceous periods the depositional environment in the Bornholm area formed a complex mixture of marine, transitional and fresh water deposits possibly influenced by a major delta (Gry 1956, Gry 1969, Gravesen, Rolle \& Surlyk 1982, Noe-Nygaard, Surlyk \& Piasecki 1987, Noe-Nygaard \& Surlyk 1988, Surlyk \& Noe-Nygaard 1986). Siderite concretions are found both in typical marine and fresh water deposits. This suggests a complex diagenetic history, in which meteoric water or sulphate depleted sea water was the dominant pore-water component. A feasible way to distinguish between these two types of pore-water environments is by stable isotope analysis of the concretionary carbonate.

The present paper reports part of a master thesis, which included development of a method for stable isotope analysis of siderite as well as geochemical investigations of selected siderite concretions (Christensen 1988).

\section{Geological setting}

The island of Bornholm is located in the central Baltic Sea at the southern extension of the Fennoscandian Borderzone or Sorgenfrei-Tornquist Zone (Berthelsen 1988). The Mesozoic (Upper Triassic to Upper Creta- 


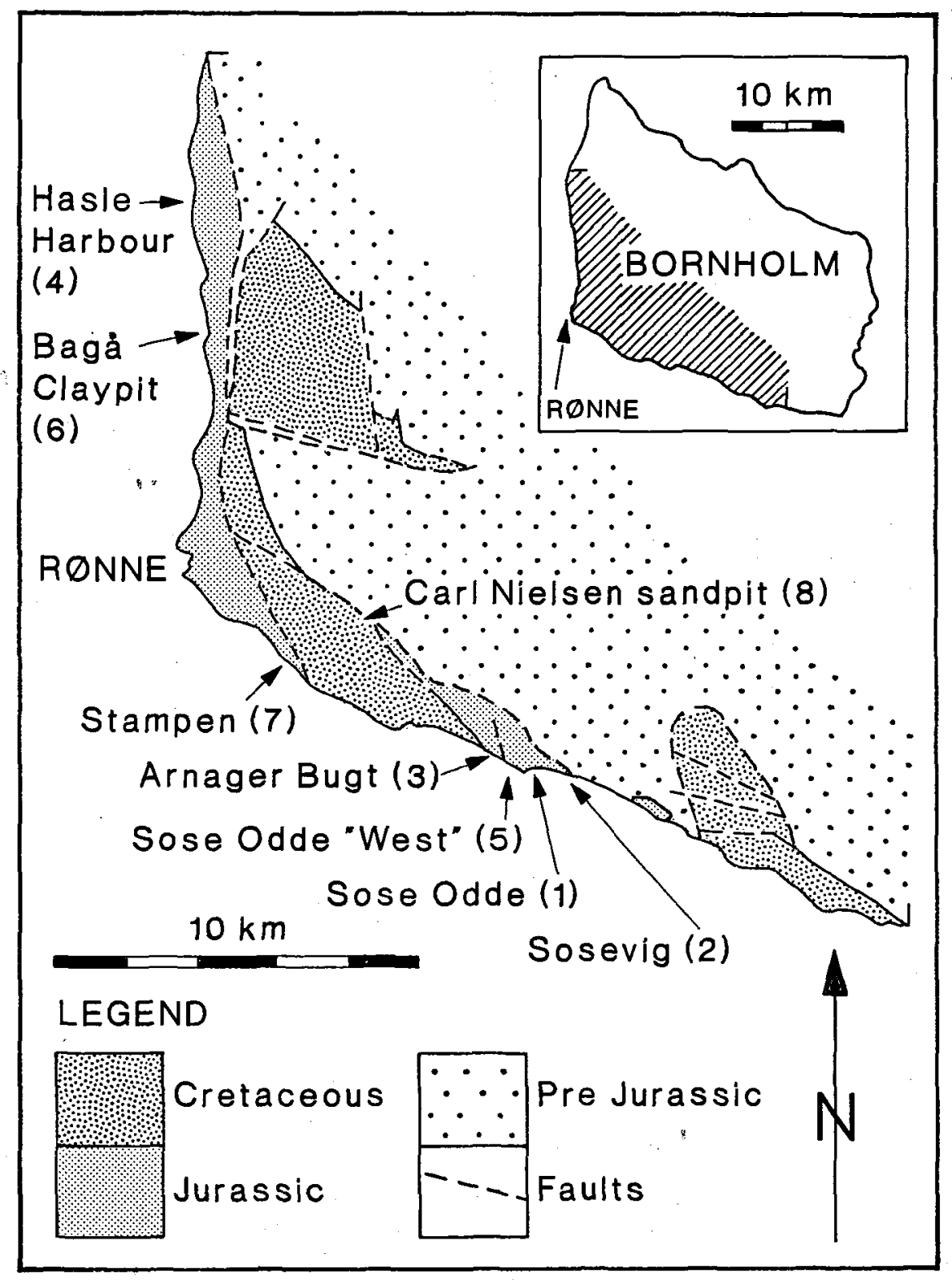

Figure 1. Localitymap of Bornholm showing the Jurassic and Cretaceous rocks as well as pre-Jurassic rocks.

ceous) deposits are known from several fault-limited blocks in the southern and southwestern part of the island (Gry 1969, Gravesen et al. 1982, see Fig. 1). The sediments included in this study range in age from Late Hettangian/Early Sinemurian to Late Berriassian/Early Valangian.The samples for the present study were collected at eight localities (Fig. 1).

Localities 1, 2 and 3 represent the Sose Bugt/Galgeløkke Member of the Rønne Formation assigned to the Hettangian and Sinemurian by Rolle (1978), Gravesen et al. (1982) and Koppelhus \& Batten (1992). At these localities the sediments consist of fine sand, mud and clay with subordinate coarse sand beds (Rolle 1978, Gravesen et al. 1982). At locality 1 delta flat deposits in the lower part of the sequence give way to intertidal and subtidal deposits in the upper part (Rolle 1978). At localities 2 and 3 fine grained, tidal deposits are exposed (Gry 1969). At localities 1, 2 and 3 the sideritic concretions are limited to the tidal deposits.

Localities 4 and 5 represent the Hasle Formation of Early Pliensbachian age (Gravesen et al. 1982). The sediments are dominated by hummocky cross stratification, coarse silt to fine sand deposited under fully marine conditions (Gravesen et al. 1982, Surlyk and Noe-Nygaard 1986). The sandbeds are irregularly cemented by siderite, calcite and ankerit (Larsen \& Friis 1991).

Localities 6 and 7 belong to the Bagå Formation of 
Toarcian to Bajocian/Bathonian age (Gry 1969, Gravesen et al. 1982, Hoelstad 1985). This formation is characterized by several fining-upwards cycles of crosslaminated sand and by heteroliths, clay and coal-seams deposited on a dominantly non-marine lower delta plain (Gry 1969). Siderite concretionsare restricted to fine-grained sediments and often contain plant debris.

Locality 8 belong to the Jydegaard Formation of Valanginian age (Gravesen et al. 1982). Fine grained lagoonal and storm generated deposits are found in the lower part of the formation (Noe-Nygaard \& Surlyk 1988). In these deposits siderite-cemented horizons are found. Bedding planes in some of the sideritecemented horizons are covered by imprints of the fresh-water bivalve Neomiodon sp.

\section{Material and analytical methods}

Forty two siderite samples were collected from the eight localities. The samples originate from discoid concretions, from continuous siderite horizons and from irregularly cemented parts of sand beds. Most samples have been collected in situ in cliff sections or quarries.

Siderite cement is easily weathered to red-brown hematitic and limonitic crusts. One sample which demonstrated different stages of surface modification, has been analysed in order to understand the chemical effects of weathering. In all other samples, weathered parts have been removed mechanically and only fresh, unweathered surfaces have been sampled.

At locality 1 , a continuous horizontal siderite band, with a thickness of $25 \mathrm{~cm}$, is exposed for c. $100 \mathrm{~m}$ along the sea cliff. Four vertical sections through this siderite band were sampled over a distance of $45 \mathrm{~m}$, in order to study the lateral and vertical variation of the siderite composition.

The analytical methods applied in this study include $\mathrm{X}$-ray diffraction (XRD), atomic absorption spectrometry (AAS) and stable isotope mass spectrometry (SIMS). In addition, carbonate cement content was determined by hydrochloric acid dissolution of the concretions. Cement content was calculated as the difference between the sample weight and the weight of the insoluble residue (matrix). The cement:matrix ratio was then calculated. This method was applied since the standard technique using sodium hydroxide backtitration is ineffective due to precipitation of weakly soluble iron hydroxides. Carbonate content is reported in volume percent to avoid the effect of density differences between siderite cement and matrix sediment. In the calculations, the matrix density, is taken as quartz $2.65 \mathrm{~g} / \mathrm{cm}^{3}$, and siderite density is $3.96 \mathrm{~g} /$ $\mathrm{cm}^{3}$.

All samples for chemical analysis were ground and sieved to a grain size between 63 and 125 microns. Carbonate and matrix mineralogy was determined semi-quantitatively by standard XRD on a Philips vertical diffractometer with a PW 1710 diffractometer
Table 1. Destinction between two types of concretions.

\begin{tabular}{|c|c|c|}
\hline Concretion type & 1 & 2 \\
\hline Lithology & mud to fine sand & fine to medium sand \\
\hline $\begin{array}{l}\text { Whole rock } \\
\text { mineralogy }\end{array}$ & $\begin{array}{l}\text { Major: Siderite } \\
\text { Minor: Quartz }\end{array}$ & $\begin{array}{l}\text { Major: Quartz. } \\
\text { Minor: Siderite, } \\
\text { calcite, } \\
\text { ankerit, } \\
\text { dolomite. }\end{array}$ \\
\hline $\begin{array}{l}\text { Matrix } \\
\text { mineralogy }\end{array}$ & $\begin{array}{l}\text { Major: Quartz. } \\
\text { Minor: Mica, } \\
\text { kaolinite, } \\
\text { pyrite, } \\
\text { feldspar. }\end{array}$ & $\begin{array}{l}\text { Major: Quartz. } \\
\text { Minor: Mica, } \\
\text { kaolinite, } \\
\text { pyrite, } \\
\text { feldspar. }\end{array}$ \\
\hline $\begin{array}{l}\text { Cement } \\
\text { content vol \% }\end{array}$ & $48-79$ & $18-44$ \\
\hline Structures & $\begin{array}{l}\text { Wavy laminated, } \\
\text { cross laminated, } \\
\text { herringbone } \\
\text { cross laminated }\end{array}$ & $\begin{array}{l}\text { Large scale } \\
\text { cross bedding, } \\
\text { structureless, } \\
\text { hummocky cross- } \\
\text { stratification }\end{array}$ \\
\hline Bioturbation & $\begin{array}{l}\text { From few burrows } \\
\text { to total biotur- } \\
\text { bation. }\end{array}$ & $\begin{array}{l}\text { No bioturbation } \\
\text { recognized. }\end{array}$ \\
\hline Colour & $\begin{array}{l}\text { Light grey to } \\
\text { yellow }\end{array}$ & $\begin{array}{l}\text { Dark yellow to } \\
\text { red brown, } \\
\text { greenish. }\end{array}$ \\
\hline $\begin{array}{l}\text { Present at } \\
\text { locality: } \\
\text { Name (number) }\end{array}$ & $\begin{array}{l}\text { Sose Odde (1) } \\
\text { Sosevig (2) } \\
\text { Arnager Bugt (3) } \\
\text { Bagågraven (6) } \\
\text { Robbedale (8) }\end{array}$ & $\begin{array}{l}\text { Hasle (4) } \\
\text { Sose Odde - } \\
\text { "West" (5) } \\
\text { Stampen (7) }\end{array}$ \\
\hline
\end{tabular}

control. The radiations used were $\mathrm{Cr} k \alpha_{1}=2.2909 \AA$ and $\mathrm{Cu} \mathrm{k \alpha} \alpha_{1}=1.5406 \AA$. Determinations of major and minor metal ions in the carbonates were performed by a Perkin-Elmer 460 atomic absorption spectrophotometer on hydrochloric acid solutions.

A standard analytical method for oxygen and carbon isotope determinations of siderite did not exist prior to this study.

The analytical difficulties reflect the low solubility of siderite at the normal carbonate preparation temperatures of 25 or $50^{\circ} \mathrm{C}$. A method was developed where $\mathrm{CO}_{2}$ was extracted from siderite using concentrated $\mathrm{H}_{3} \mathrm{PO}_{4}$ at $150^{\circ} \mathrm{C}$ for two hours as suggested by Rosenbaum \& Sheppard (1986). The reaction took place in a heat box in evacuated and welded glass tubes in order to prevent leaking of the developed $\mathrm{CO}_{2}$. In the standardprocedure 5-7 mg of sample material reacted with $1.5 \mathrm{ml} \mathrm{H}_{3} \mathrm{PO}_{4}$. The procedure has been described in detail in Christensen (1988). After reaction, the evolved carbon dioxide was extracted immediately and released into a vacuum system and purified following standard procedures (Buchardt 1974). The carbon and oxygen isotope composition of the carbon dioxide was then 
Table 2. Results of the systematic analysis from Sose Odde, locality 1.

\begin{tabular}{|c|c|c|c|c|c|c|c|c|c|c|}
\hline \multirow[t]{2}{*}{$\begin{array}{l}\left.\text { Sample }{ }^{1}\right) \\
\text { nr. }\end{array}$} & \multirow[t]{2}{*}{ level ${ }^{2}$ ) } & \multicolumn{2}{|c|}{ Mineralogy $y^{3}$ ) } & \multicolumn{4}{|c|}{$\begin{array}{l}\text { Carbonate composition } \\
\text { mole } \%{ }^{4} \text { ) }\end{array}$} & \multirow{2}{*}{$\begin{array}{l}\text { Cement } \\
\text { content } \\
\text { vol \% }\end{array}$} & \multicolumn{2}{|c|}{$\begin{array}{l}\text { Isotopic compo- } \\
\text { sition o/oo }\end{array}$} \\
\hline & & Qz. & Sid. & $\mathrm{Fe}$ & $\mathrm{Ca}$ & $\mathrm{Mg}$ & $\mathrm{Mn}$ & & $\delta^{18} \mathrm{O}_{\text {sMOW }}$ & $\delta^{13} \mathrm{C}_{\mathrm{PDB}}$ \\
\hline $4 \mathrm{I}$ & 24.4 & - & - & 95.8 & 2.44 & 1.14 & 0.65 & 62 & 27.9 & -5.0 \\
\hline 4 II & 21.6 & TR & $\mathrm{XXX}$ & 94.1 & 3.70 & 1.34 & 0.84 & 77 & 26.1 & -7.4 \\
\hline 4 III & 19.3 & - & - & 95.2 & 3.30 & 0.88 & 0.66 & 41 & 26.1 & -6.6 \\
\hline $4 \mathrm{IV}$ & 17.3 & $\mathrm{X}$ & XXX & 94.4 & 3.49 & 1.22 & 0.87 & 59 & 25.3 & -7.6 \\
\hline $4 \mathrm{~V}$ & 14.9 & $\mathrm{X}$ & XXX & 94.5 & 3.53 & 1.18 & 0.84 & 66 & 25.3 & -7.6 \\
\hline $5 \mathrm{VI}$ & 11.9 & $\mathrm{X}$ & $\mathrm{XXX}$ & 94.4 & 3.66 & 1.11 & 0.80 & 69 & 26.5 & -6.4 \\
\hline 5 VII & 9.2 & - & - & 94.3 & 3.54 & 1.35 & 0.84 & 63 & 26.5 & -6.5 \\
\hline 5 VIII & 7.5 & $X$ & $X X X$ & 94.9 & 3.00 & 1.20 & 0.90 & 61 & 26.7 & -6.7 \\
\hline $5 \mathrm{IX}$ & 3.4 & - & - & 95.5 & 2.64 & 1.13 & 0.75 & 72 & 27.9 & -5.2 \\
\hline $5 x$ & 1.5 & $\mathrm{X}$ & $\mathrm{XXX}$ & 95.8 & 2.37 & 0.98 & 0.84 & $7 \overline{8}$ & 28.4 & -5.3 \\
\hline
\end{tabular}

1) Samples collected through the siderite bands are given roman numerals from top to bottom.

2) Sample level is measured in $\mathrm{cm}$ relative to the base of the siderite band.

3) Semi-quantitative estimate of mineralogy are made on the basis of XRD diagrams. Qz. = Quartz and Sid. = Siderite.

Contents are described as follows: $\mathrm{TR}=$ traces, $\mathrm{X}=$ medium content, $\mathrm{XXX}=$ high content.

4) $\mathrm{Sr}$ is found in all samples, the content is in the range from 29 to $40 \mathrm{ppm}$.

determined in a Finnigen MAT 250 mass spectrometer, corrected according to Craig (1957) and calculated as o/oo $\delta$ values relative to a working standard (Ivigtut siderite IS1). IS1 was used as a reference level for all stable isotope analyses of the siderite samples. When fluorination of IS1 failed to give the exact $\delta^{18} \mathrm{O}$ value of the siderite, the $\delta^{18} \mathrm{O}_{\mathrm{PDB}}$ of IS1 was achieved by calculation. The $\delta^{18} \mathrm{O}_{\mathrm{PBB}}$ value was calculated using the relative value of IS1 to the reference gas of the mass spectrometer and the well established $\delta^{18} \mathrm{O}_{\mathrm{PDB}}$ value of the local calcite standard (LEO. STD.). Carbon isotope values are given relative to the PDB standard. The oxygen fractionation factor $(\alpha)$ which has to be applied is mineral and temperature dependant. For siderite dissolved at $150^{\circ} \mathrm{C}$ a fractionation factor of $\alpha=1.00771$ was used as given by Rosenbaum \& Sheppard (1986). The oxygen isotopic values are further given relative to the SMOW standard. Reproducibility of the stable isotope analysis given as standard deviation, $x \pm$ s.d. is better than \pm 0.11 o/oo.

\section{Results and discussion}

The investigated concretions include two distinctly different types based on matrix grain size and geochemistry (see Table 1).

Type 1 concretions with a matrix in the range from clay to fine sand and type 2 concretions with a matrix in the range from fine to medium sand. The two types of concretions are discussed separately with greater emphasis on the better represented type 1 concretions.

The analytical results are given in Tables $2-3$ and in Figs 2-3. Table 2 and Fig. 2 present data from one cross section in the siderite horizon at Sose Odde (locality 1). Table 3 includes all other analytical results, and Fig. 3 shows stable isotope analyses from all samples.

\section{Type 1 concretions}

The concretions belonging to this group are considered to be of early diagenetic, pre-compactional origin. This is based on the observations of the preservation of uncompacted burrows in the concretionary bed (horizon) at locality 1 and the occurrence of uncrushed mollusc shells at locality 8 .

The investigation of thin sections of type 1 concretions are in accordance with this interpretation. As discussed later type 2 concretions have been subject to diagenesis (Larsen and Friis 1991). Comparing the two types of concretions it is considered not likely that type 1 concretions have undergone recrystallization or replacement.

At locality 1, the bioturbation includes burrows of Chondrites, Arenicolites and Planolites (pers. comm. R.G. Bromley 1988), all characteristic of a soft bottom environment at the time of bioturbation. At locality 8 , bedding planes are covered by uncrushed Neomiodon shells preserved as moulds in the siderite (Noe-Nygaard et al. 1987).

Type 1 concretions probably formed as intergranular cement, not as hardgrounds or crusts at the water-sediment interface. This is demonstrated by the lack of traces from boring or encrusting organisms on the upper surfaces of the concretions. At all investigated localities, type 1 concretions formed in connection with alternating beds of sand and mud. This, together with the overall horizontal extension of the concretions, suggests a dominantly horizontal precipitation of siderite governed by permeability differences.

\section{Petrography}

The matrix of the type 1 concretions is dominated by quartz in the silt fraction. Minor amounts of clay (kaolinite), mica, feldspar and pyrite are found in most 
Table 3. Analytical results from localities 1 to 8 . For explanations to the columns, see table 2 .

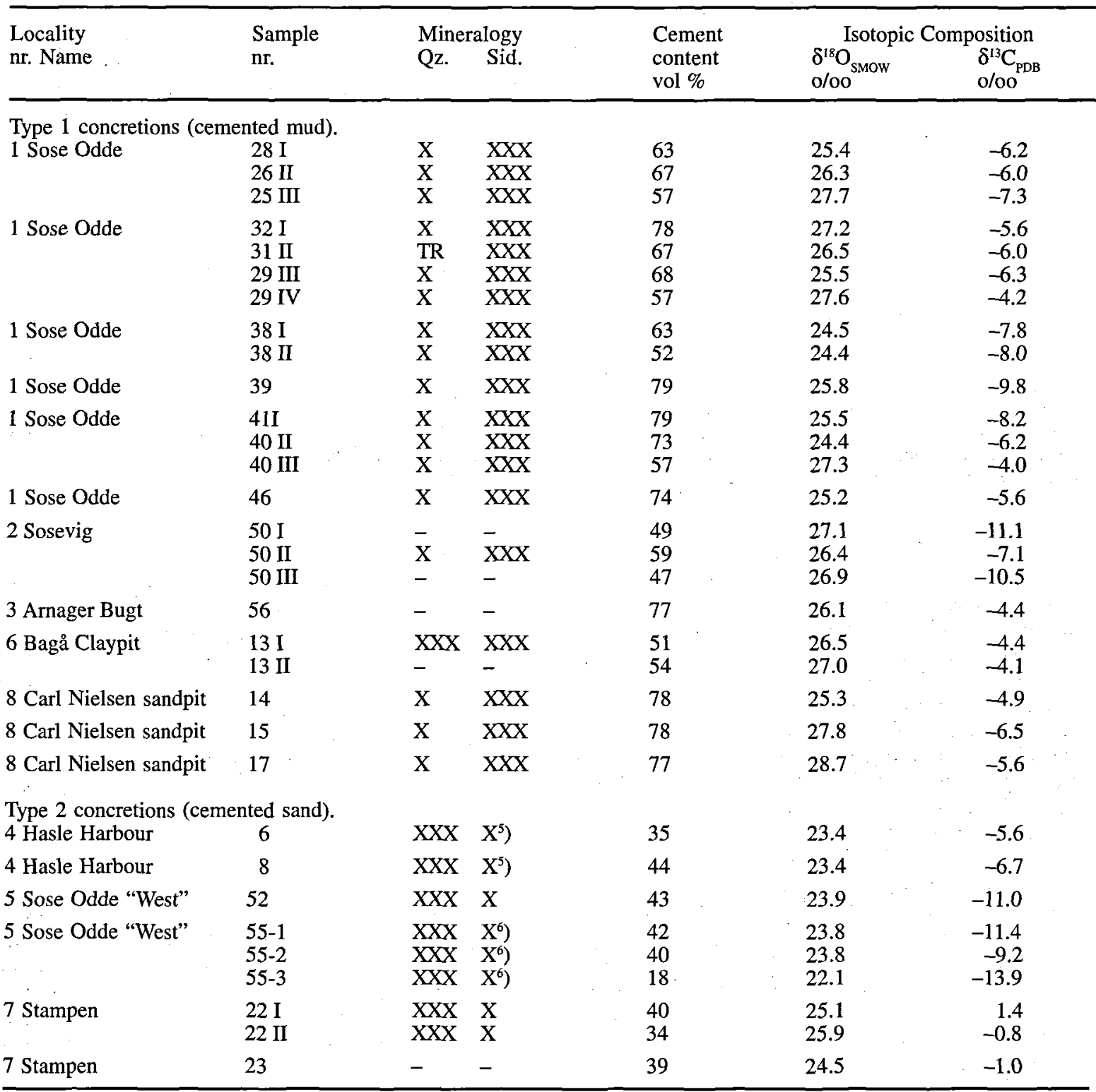

5) Samples 6 and 8 contain traces of dolomite.

6) The samples 55-1, 55-2 and 55-3 are collected on the basis of increasing weathering.

of the samples. Shell fragments are extremely rare and when found, as in the Neomiodon beds at locality 8 , recrystallized into calcite. Concretionary cement is siderite with a general composition corresponding to a formula of $\left(\mathrm{Fe}_{95} \mathrm{Ca}_{.03} \mathrm{Mg}_{01} \mathrm{Mn}_{.01}\right) \mathrm{CO}_{3}$ (see Table 2), with $\mathrm{Sr}$ in the range of 29 to $40 \mathrm{ppm}$. The cation composition of the siderite shows some variations as seen in Fig. 2. In thin sections, the carbonate is seen to be composed of tightly intergrowing crystals in the micritic to fine sparitic range.

\section{Cement/matrix ratios}

The investigated concretions contain from 49 to 79 vol\% cement. Intra-concretionary variations are large, up to $20 \mathrm{vol} \%$, and are not directly related to concretionary growth. Micritic and microsparitic, non-replacive concretions of the type investigated in the present study form by cement precipitation in the pore space of the sediment (Raiswell 1971, Curtis et al. 1986). In clayey to muddy, fine-grained sediments, porosity will decrease systematically with burial depth (Hamilton 1976, Baldwin \& Butler 1985), and the cement to 


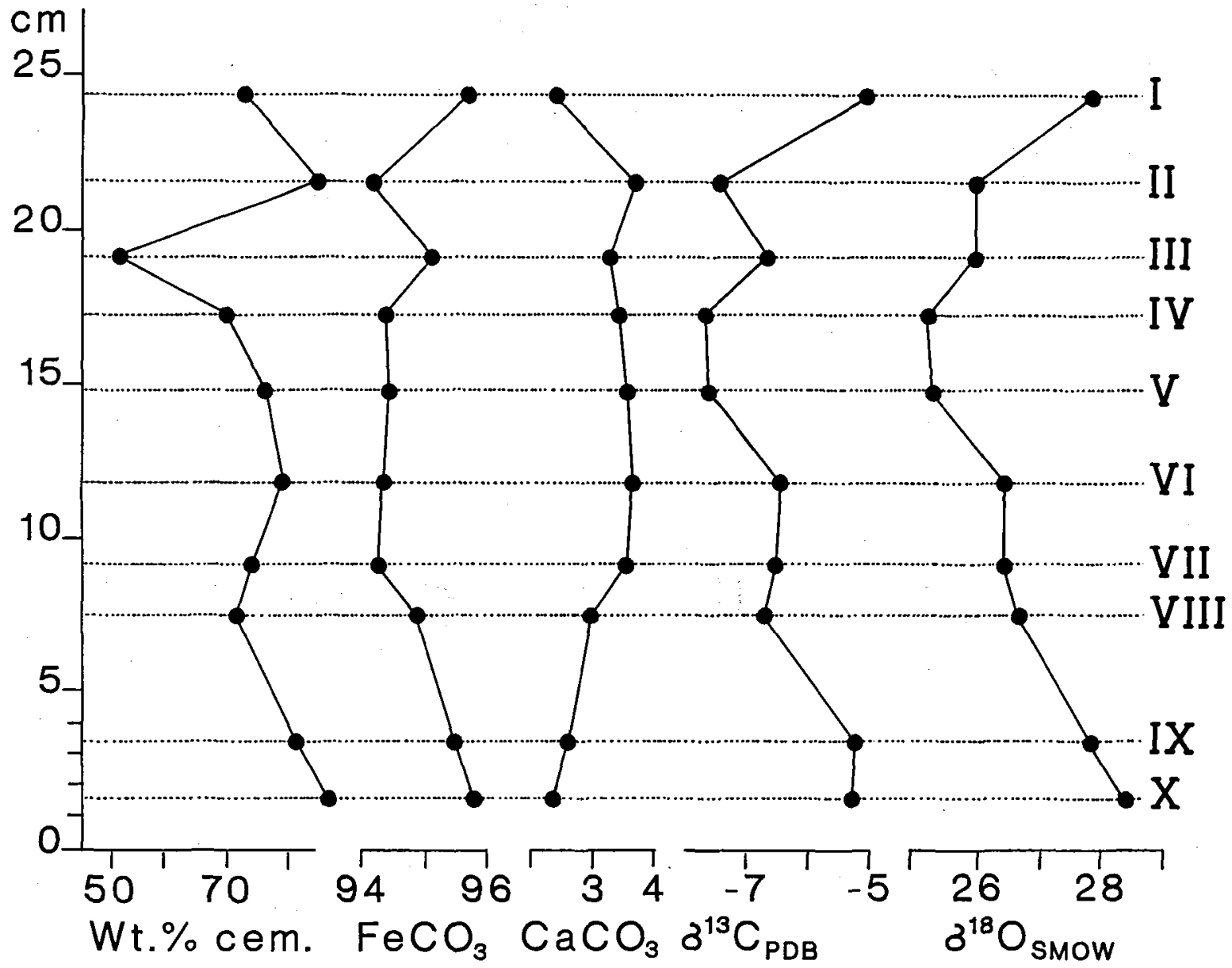

\section{Carbonate phase composition in mole \%}

Figure 2. Geochemical analysis through the siderite band from locality 1, Sose Odde.

matrix ratio of concretions formed in such rocks will be a measure of the degree of compaction and thus of burial depth. The relationship, however, will be masked by variations in initial porosity of the matrix sediments. Cement contents of 70 to 80 vol\% as seen in the concretions from localities 1,3 and 8 correspond to matrix porosities characteristic of uncompacted mud and reflect precompactional growth. This observation is in accordance with the occurrence of uncompacted burrows in these concretions as discussed above.

Concretions from localities 2 and 6 have a significantly lower cement content (see Table 3 ). Lack of bioturbation in these concretions makes it difficult to reach a conclusion about growth time relative to compaction. The cement content however, does indicate a somewhat later, probably syncompactional origin.

The concretion from locality 2 is the only one showing a "classical" development with decreasing cement content from the centre towards the margins. This development is generally interpreted as being caused by cement precipitation during progressive sediment compaction (Raiswell 1971).

\section{Siderite precipitation relative to pore-water environment}

Siderite precipitation requires pore water with high $\mathrm{Fe}$ and bicarbonate activities in a reducing environment. Ofimportance is that the pore water is devoid of sulphate ions. Meteoric water meet this demand. In sea water environments sulphate ions can be removed by bacterial reduction. The bacterial sulphate reduction result in pyrite precipitation and pore water with low sulphate content. This modified sea water thus meet the demand for siderite precipitation.

Pyrite concretions are found in the tidal deposits at locality 1 (see Table 2), 2, 3 and 8 indicating that sulphate reduction took place at least in part of the sedimentary column. The close relationship between pyrite 
Figure $3 . \delta^{13} \mathrm{C}_{\mathrm{PDB}}$ versus $\delta^{18} \mathrm{O}_{\text {smow }}$ plot showing all stable isotope analysis in this project. Numbers refer to the localities.

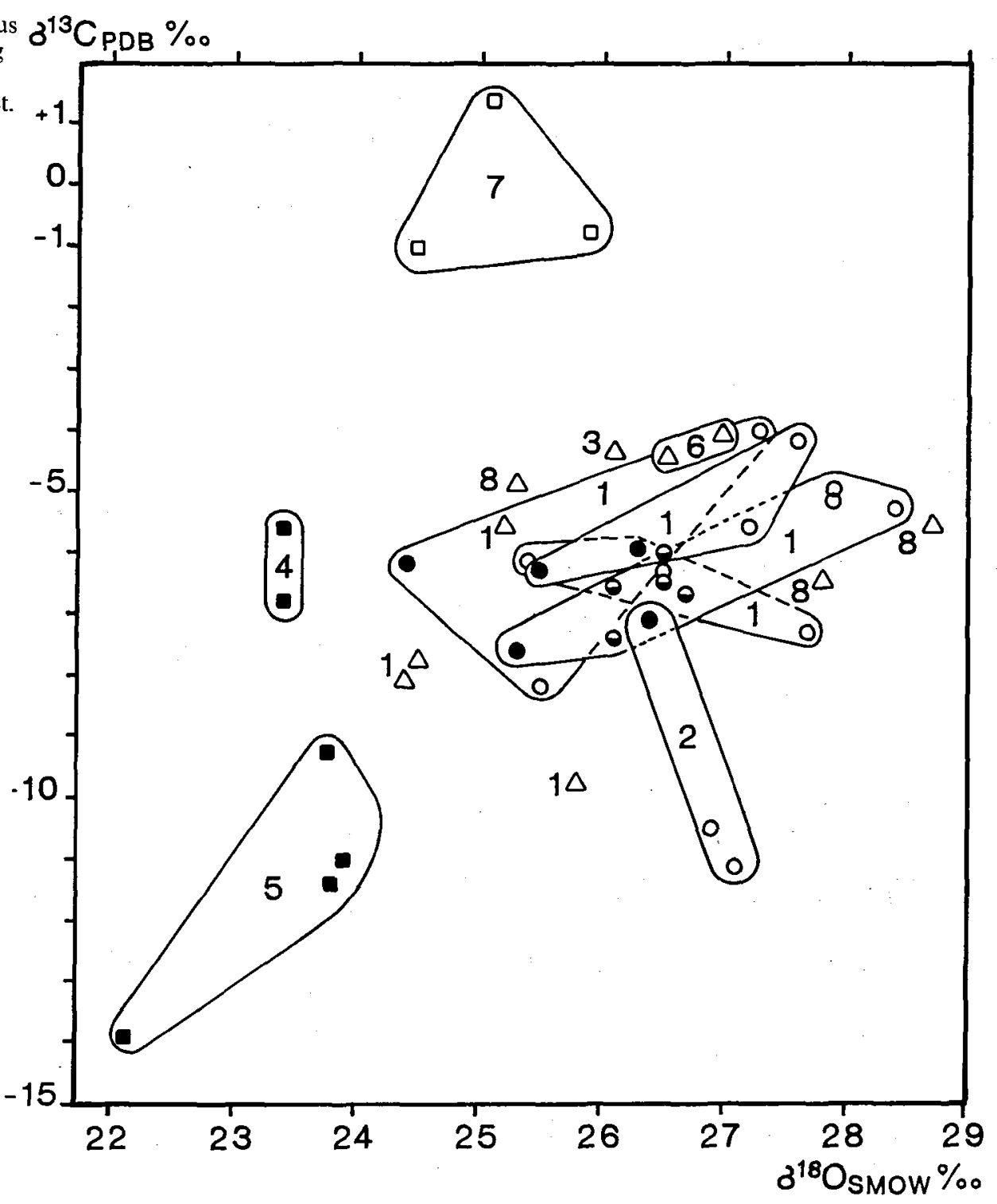

Type 1 concretions:

- Sample from central part of section.

- Sample from intermediary part of section.

- Sample from marginal part of section.

$\triangle \quad$ Sample from randomly collected concretions.

Type 2 concretions:

- Sample from unweathered concretion.

- Sample from weathered concretion. 
and siderite observed in these sections reflects local sulphate depletion of the pore water. Depletion took place either by pyrite precipitation or by mixing of sea water with non-marine meteoric waters seeping into the marine sediments through aquifers. In both cases replenishment of sulphate ions from overlying sea water had to be sealed off, e.g. by weakly permeable mud layers as suggested by Sellwood (1971).

\section{Stable isotope compositions}

The pore water environment can be further indicated by the stable isotope compositions (see Figs 2 - 3). Stable isotope compositions range between -14.1 and $+1.4 \mathrm{o} / \mathrm{oo} \delta^{13} \mathrm{C}_{\mathrm{PDB}}$ and between +24.2 and $+28.7 \mathrm{o} / \mathrm{oo}$ $\delta^{18} \mathrm{O}_{\text {smow }}$. The ranges of the stable isotope values indicate certain conditions in the environment of precipitation as discussed below. Three assumptions have to be made concerning the interpretation of the $\delta^{18} \mathrm{O}$ composition of the siderite, bottom water temperature, $\delta^{18} \mathrm{O}$ value of the sea water and the fresh water $\delta^{18} \mathrm{O}$ value.

I) Sea bottom water temperatures in non-glaciated Jurassic times of $20^{\circ} \mathrm{C}$ have been suggested on the basis of climatological investigations (Drewry, Ramsey \& Smith 1974).

II) In accordance with I) a sea water $\delta^{18} \mathrm{O}$ value of -1.2 o/oo can be interpreted (Shackleton \& Kennett 1975).

III) The $\delta^{18} \mathrm{O}$ value of Jurassic fresh water is assumed to be -6 o/oo $\delta^{18} \mathrm{O}_{\text {smow }}$ :

These assumptions give marine carbonate with $\delta^{18} \mathrm{O}$ values of c. $29 \mathrm{o} / \mathrm{oo} \delta^{18} \mathrm{O}_{\text {SMOw }}$ and fresh water carbonates of c. $24 \mathrm{o} / 00 \delta^{18} \mathrm{O}_{\text {SMOw }}$. As a consequence of a precompactional early diagenetic origin of the concretions, temperature dependent $\delta^{18} \mathrm{O}$ variations within the siderite would be of no importance.

The carbon in the siderite concretions originated in atmospheric carbon dioxide dissolved in sea water. Sea water bicarbonate is interpreted to have a $\delta^{13} \mathrm{C}$ value of $0 \mathrm{o} / \mathrm{oo} \delta^{13} \mathrm{C}_{\mathrm{PDD}}$. A second source of carbon is bicarbonate derived from the dissolution of shell fragments and the breakdown of organic matter. Organic matter of the Jurassic rocks of Bornholm has $\delta^{13} \mathrm{C}$ values of -27.7 to -21.8 o/oo $\delta^{13} \mathrm{C}_{\mathrm{PDB}}$ (Buchardt \& Cederberg 1987). Bacterial oxidation and sulphate reduction release $\mathrm{CO}_{2}$ with $\delta^{13} \mathrm{C}$ values like the original organic matter (Irwin et al. 1977). Only negligible fractionation of the carbon isotopes occurs during carbonate precipitation.

Based on the assumptions made above, the central part of the siderite horizon at locality 1 reflects siderite precipitation in fresh pore water where bicarbonate composition is affected by breakdown of organic matter. The margins, however, show more positive $\delta^{18} \mathrm{O}$ values resulting from precipitation in fresh pore water mixed with water of brackish or marine origin. Accordingly $\delta^{13} \mathrm{C}$ values tend to reflect precipitation in water enriched in marine bicarbonate. Inthree of the four cross sections, this is the trend seen in the stable isotope compositions (see Table 3, samples 29-32 and 40-41).

At locality 2 the centre of the siderite layer has $\delta^{18} \mathrm{O}$ and $\delta^{13} \mathrm{C}$ compositions like the intermediate part of the siderite layer at locality 1 . In the marginal parts of the layer, the $\delta^{13} \mathrm{C}$ values decrease due to the increased influence of organic matter breakdown. These results are in accordance with the interpretation of syn-compactional siderite precipitation at locality 2 .

As Fig. 3 shows, the isotopic composition of concretions from localities 3,6 and 8 falls within the same compositional field as samples from locality 1 . The pore-water environment at the three localities is the same although interpretations of the depositional environment are different.

\section{Type 2 concretions}

\section{Field evidence}

Type 2 concretions are distinguished by a sandy matrix and occur as loosely cemented parts in sand units. Sedimentary structures, where present, show no deformation in relation to the outline of the concretions, indicating syncompactional cementation. Recent investigations by Larsen and Friis (1991) reveal a complicated diagenetic history of these rocks. Siderite have precipitated in several stages during diagenesis.

\section{Petrographic evidence}

The matrix of type 2 concretions consists of medium sized quartz sand, with small amounts of kaolinite, mica and feldspar. Type 2 concretions are cemented by siderite and in some cases reveal traces of dolomite. The rocks further contain lithic fragments, pyrite, calcite and ankerit (Larsen \& Friis, 1991) which has not been found in this study. Where siderite and dolomite were present in the concretions the relation was not studied because it fell outside the aim of this investigation. The sparitic siderite cement of one type 2 concretion analyzed displayed a cation composition like the type 1 concretions.

\section{Matrix/cement ratio}

In type 2 concretions, the matrix/cement ratio is usually high with 40 to 44 vol\% carbonate, due to recrystallisation of the rocks (Larsen \& Friis, 1991). Taking this into account the depth of concretion formation cannot be interpreted by matrix/cement ratio.

Some type 2 concretions contain less than 18 vol\% cement (see Table 2) these shows signs of deep weathering, represented by dark yellow to red colouration.

\section{Stable isotope compositions}

The stable isotope composition of type 2 concretions 
differs much more than in type 1 concretions, reflecting different diagenetic environments and recent weathering (Fig. 3).

In concretions from locality 4 , Hasle Harbour, $\delta^{18} \mathrm{O}$ values are calculated as if only siderite were present, although the samples analyzed contains traces of dolomite besides siderite. The two carbonate fractions in theconcretion were not separated. The $\delta^{18} \mathrm{O}$ values reflect precipitation in pore water of fresh water composition. The $\delta^{13} \mathrm{C}$ values of these concretions indicate precipitation under conditions of oxidation of organic matter.

The $\delta^{13} \mathrm{C}_{\mathrm{PDB}}$ compositions resemble compositions seen in type 1 concretions.

From locality 5 , the four samples show weathering to various degrees. The extent of weathering was estimated from the increasingly red colouration of the samples, and from the decrease in cement content in one sample. Samples showing weathering have decreasing $\delta^{18} \mathrm{O}$ and $\delta^{13} \mathrm{C}$ values compared to unweathered samples (figure 3 ).

Stable isotope compositions of concretions at locality 7 reveal "fresh water" $\delta^{18} \mathrm{O}$ values. $\delta^{13} \mathrm{C}$ values, however, show precipitation of carbonate in equilibrium with sea water bicarbonate.

\section{Conclusions}

Type 1 concretions, formed in a variety of sedimentological settings from fresh water swamps to tidal environments. Siderite precipitation started shortly after burial in sediment containing up to $80 \mathrm{vol} \%$ water and terminated before the sediment had sustained compaction. This is seen in the high cement content throughout the concretions and minor changes in cation compositions.

Siderite precipitation started where fresh pore water seeped into the sediment column through layers of coarser grained material or where a fresh water lens was present below the sea bottom.

The environment of precipitation was characterized by organic matter breakdown and high $\mathrm{Fe}$ contents. Weakly permeable mud layers prevented large scale pyrite precipitation in the border between fresh and "marine" pore water. High Fe contents resulted from leaching of soil or deeply weathered, kaolinized rocks to the north.

Oxygen isotope compositions point to siderite precipitation from pore water derived by mixing of fresh and brackish water. Pore waters of marine composition have not been found; this indicates the presence of brackish waters in the tidal and coastal marine environments of Bornholm in Jurassic times (Noe-Nygaard \& Surlyk 1988).

$\delta^{13} \mathrm{C}$ compositions reflect the mixing of carbon released by bacterial oxidation of organic matter and marine bicarbonate.

Concretions precipitated during sediment compac- tion show fresh-water $\delta^{18} \mathrm{O}$ compositions, while carbon isotope compositions indicate the increasing influence of organic matter breakdown.

The stable isotope values of type 2 concretions indicate precipitation in fresh to brackish pore water. Considering the diagenesis of the rocks these analysis may show a mixture of the environments where siderite precipitated.

Finally it may be concluded that only unweathered samples of siderite give useful information about porewater composition at the time of siderite precipitation. Weathered siderite shows the effects of secondary leaching.

\section{Acknowledgements}

The author is grateful to Dr. B. Buchardt, Geological Institute, University of Copenhagen, for his helpin preparing this manuscript. I thank Dr. N. Noe-Nygaard, Geological Institute, University of Copenhagen, and Dr. T. Laier, Geological Survey of Denmark, for helpful comments on the manuscript, and Dr. J. Bailey, Geological Institute, University of Copenhagen, for improving my english. $\mathrm{H}$. Egelund, Geological Institute, University of Copenhagen, prepared the drawings.

\section{Dansk sammendrag}

Sideritkonkretioner findes spredt $\mathrm{i}$ de nedre jurassiske til nedre kretassiske sedimentære bjergarter $i$ det vestlige og sydvestlige Bornholm. Den diagenetiske historie af konkretionerne, der forekommer som diskoide legemer og kontinuerte lag, er undersøgt ved hjælp af geokemiske metoder. På 8 lokaliteter (Fig. 1) er indsamlet 42 prøver, inddelt i 2 typer efter matrixsammensætning (Tabel 1). Prøvematerialet er analyseret for cementindhold, mineralogi, kationsammensætning og stabilisotopsammensætning (Tabel 2 - 3, Figs 2 - 3). Sideritkonkretionerne dannedes prækompaktionelt, hvilket ses af velbevarede gravegange og højt cementindhold. Oxygenisotopanalyserne viser, at konkretionerne dannedes $\mathrm{i}$ fersk porevand, mudderkonkretioner (type 1) afspejler desuden en ændring af porevandssammensatningen til brakvand. $\delta^{13} \mathrm{C}$-sammensætningerne afspejler dannelse under indflydelse af bakteriel oxidation af organisk materiale samt af marint bikarbonat. Enkelte prøver afspejler forvitring ved lavere værdier af både oxygen- og carbonisotopsammensætninger.

\section{References}

Baldwin, B. \& Butler, C. O. 1985: Compaction curves. American Association of Petroleum Geologists, Bulletin 69, 622-626.

Berthelsen, A. (Chair person) 1988: European Geotraverse, EUGENO - S Working Group. Crustal structure and tecto- 
nic evolution of the transition between the Baltic Shield and the North German Caledonides (The EUGENO-S Project). Tectonophysics 150, 253-348.

Buchardt, B. 1974: ${ }^{18} \mathrm{O} /{ }^{16} \mathrm{O}$-forholdet i skal materiale fra danske tertiær-aflejringer og dets tolkning som palæotemperaturer. Københavns Universitet, Unpublished M.Sc. thesis 214 pp.

Buchardt, B, \& Cederberg, T. 1987: Stabil isotop geokemi i moderbjergarter, olie og gas i Danmark. EFP-83 PROJEKT, Afsluttende Rapport. Institut for Historisk Geologi, Københavns Universitet.

Buchardt, B. \& Nielsen, A.T. 1985: Carbon and oxygen isotope composition of Cambro-Silurian limestone and anthraconite from Bornholm: Evidence for deep burial diagenesis. Bulletin of the Geological Society of Denmark $33,415-435$.

Christensen, N. B. 1988: C- og O-isotopanalyser af jurassiske sideritkonkretioner fra Bornholm. Institut for Historisk Geologi og Palæontologi, Københavns Universitet. Unpublished M.Sc. thesis, $138 \mathrm{pp}$.

Coleman, M. L. \& Raiswell, R. 1981: Carbon, oxygen and sulphur isotope variations in concretions from the Upper Lias of N.E. England. Geochimica et Cosmochimica Acta 45, 329-340.

Craig, H. 1957: Isotope standards for carbon and oxygen and correction factors for mass spectrometric analysis of carbon dioxide. Geochimica et Cosmochimica Acta 12, 133-149.

Curtis, C. D., Coleman, M. L. \& Love, L. G. 1986: Pore waterevolution during sediment burial from isotopic and mineralchemistry af calcite, dolomite and siderite concretions. Geochimica et Cosmochimica Acta 50, 2321-2334.

Curtis, C. D. \& Coleman, M. L. 1986: Controls on the precipitation of early diagenetic calcite, dolomite and siderite concretions in complex depositional sequences. In: Gautier, D. L. (Ed.), Roles of organic matter in sediment diagenesis. Society of Economic Paleontologists \& Mineralogists, Special Publication 38, 23-33.

Curtis, C. D., Petrowski, C. \& Oertel, G. 1972: Stable carbon isotope ratios within carbonate concretions: a clue to place and time of formation. Nature 235, 98-100.

Drewry, G. E., Ramsay, A. T. S. \& Smith, A. G. 1974: Climatically controlled sediments, the geomagnetic field, and trade wind belts in Phanerozoic time. Journal of Geology 82, 531-553.

Gautier, D. L. 1982: Siderite concretions: Indicators of early diagenesis in the Gammon Shale (Cretaceous), Journal of Sedimentary Petrology 52, 859-871.

Gautier, D. L. 1985: Interpretation of early diagenesis in ancient marine sediments. In: Society of Economic Paleontologists \& Mineralogists, Short Course 17, 6-78.

Gravesen, P., Rolle, F. \& Surlyk, F. 1982: Lithostratigraphy and sedimentary evolution of the Triassic, Jurassic and Lower Cretaceous of Bornholm, Denmark. Danmarks Geologiske Unders $\emptyset$ gelse B7, 51 pp.

Gry, H. 1956: Wealdenaflejringerne på Bornholm. Meddelelser fra Dansk Geologisk Forening, København 13, 134140.

Gry, H. 1969: Megaspores from the Jurassic of the island of Bornholm, Denmark. Meddelelser fra Dansk Geologisk Forening, København 19, 68-89.

Hamilton, E. L. 1976: Variations of density and porosity with depth in deepsea sediments. Journal of Sedimentary Petrology 46, 280-300.

Hoelstad, T. 1985: Palynology of the uppermost Lower to
Middle Jurassic strata on Bornholm, Denmark. Bulletin of the Geological Society of Denmark 34, 111-132.

Irwin, H. 1980: Early diagenetic carbonate precipitation and pore fluid migration in the Kimmeridge Clay of Dorset, England. Sedimentology 27, 577-591.

Irwin, H., Curtis, C. \& Coleman, M. 1977: Isotopic evidence for source of diagenetic carbonates formed during burial of organic-rich sediments. Nature 269, 209-213.

Koppelhus, E. B. \& Batten, D. J. 1992: Megaspore assemblages from the Jurassic and lowermost Cretaceous of Bornholm, Denmark. Danmarks Geologiske Unders $\varnothing$ gelse A32, $81 \mathrm{pp}$.

Larsen, O. H. \& Friis, H. 1991: Petrography, diagenesis and pore-water evolution of a shallow marine sandstone (Hasle Formation, Lower Jurassic, Bornholm, Denmark). Sedimentary Geology 72, 269-284.

Machemer, S. D. \& Hutcheon, I. 1988: Geochemistry of Early Carbonate Cements in the Cardium Formation, Central Alberta. Journal of Sedimentary Petrology 58, 136147.

Mozley, P. S. \& Carothers, W. W. 1992: Elemental and Isotopic Composition of Siderite in the Kuparuk Formation, Alaska: Effect of Microbial Activity and Water/Sediment Interaction on Early Pore-Water Chemistry. Journal of Sedimentary Petrology 62, 681-692.

Noe-Nygaard, N., Surlyk, F. \& Piasecki, S. 1987: Bivalve mass mortality caused by toxic dinoflagellate blooms in a Berriassian-Valanginian Lagoon, Bornholm, Denmark. Palaios 2,263-273.

Noe-Nygaard, N. \& Surlyk, F. 1988: Washover fan and brackish bay sedimentation in the Berriasian-Valanginian of Bornholm, Denmark. Sedimentology 35, 197-217.

Pirrie, D. \& Marshall, J. D. 1991: Field relationships and stable isotope geochemistry of concretions from James Ross Island, Antarctica. Sedimentary Geology 71, 137150.

Raiswell, R. 1971: The growth of Cambrian and Liassic concretions. Sedimentology 17, 147-171.

Raiswell, R. 1976: The microbiological formation of carbonate concretions in Upper Lias of N.E. England. Chemical Geology 18, 227-244.

Rolle, F. 1978: Sedimentationsmiljøer i Nedre Jura på Bornholm. Unpublished M.Sc. thesis, København, 85 pp., incl. enclosures.

Rosenbaum, J. \& Sheppard, S. M. F. 1986: An isotopic study of siderites, dolomites and ankerites at high temperatures. Geochimica et Cosmochimica Acta 50, 1147-1150.

Sellwood, B. W. 1971: The genesis of some sideritic beds in the Yorkshire Lias (England). Journal of Sedimentary Petrology 41, 854-858.

Shackleton, N. J. \& Kennett, J. P. 1975: Paleotemperature history of the Cenozoic and the initiation of Antarctic glaciations: Oxygen and carbon isotope analysis in DSDP sites 277, 279, and 281. In: White, S.M. (Ed.). Initial Report of the Deep Sea Drilling Project XXIX, 743-755.

Surlyk, F. \& Noe-Nygaard, N. 1986: Hummocky crossstratification from the Lower Jurassic Hasle Formation of Bornholm, Denmark. Sedimentary Geology 46, 259 273.

Wilkinson, M. 1991: The concretions of the Bearreraig Sandstone Formation: geometry and geochemistry. Sedimentology $38,899-912$. 